УДК: 352:347.63-058.862

\title{
Ресурсне забезпечення в організації протидії соціальному сирітству на рівні місцевого самоврядування
}

\author{
А.П. Я્રЩУК \\ Національна акалемія державного управління при Презилентові України, \\ м. Kиїв, Україна, E-mail: Laurum@ukr.net
}

\begin{abstract}
Авторське резюме
У статті зазначено, що діюча система органів виконавчої влади та місцевого самоврядування у сфері соціального захисту дітей залишається нескоординованою, відповідальність розділена між різними центральними та місцевими органами виконавчої влади. В результаті координація та методологічне забезпечення діяльності центральних та місцевих органів виконавчої влади та місцевого самоврядування у сфері реалізації державної політики щодо протидії соціального сирітства покладена на $\mathrm{Mi}$ ністерство соціальної політики України. Виявлено, що всі важливі рішення стосовно дітей вирішуються на рівні районної державної адміністрації. Громада міста, села, селища залишається осторонь у вирішенні цих завдань. Це, звичайно, не стосується міст обласного значення, де у складі виконкому є служба у справах дітей.

3'ясовано, що Законом України «Про місцеве самоврядування» передбачено залучення громадськості до активної участі у вирішенні питань територіальної громади. Однак організація такої роботи на місцях безперечно потребує ресурсів.

Проаналізовано підходи до класифікації ресурсів, виокремлено ті, які мають практичне значення й використовуються в процесі формування ресурсної бази в організації протидії соціальному сирітству на рівні місцевого самоврядування.

Доведено, що організація протидії соціального сирітства на рівні місцевого самоврядування - це діяльність з використанням управлінських методів та прийомів, що потребує вдосконалення умов, форм та методик надання соціальних послуг сім'ям, які опинилися у складних життєвих обставинах, а ресурси - це сукупність можливостей для розв'язання індивідуальних та соціальних потреб.
\end{abstract}

Ключові слова: ресурси, територіальна громада, організація протидії соціального сирітства, місцеве самоврядування.

\section{The resource support in the organization combating the social orphanage at the local self-government level}

\author{
L.P. YASHCHUK \\ National academy for public administration under the President of Ukraine, \\ Kyiv, Ukraine, E-mail: Laurum@ukr.net
}

\begin{abstract}
The article defines that the current system of the executive bodies and local self-government in the field of social child protection is still uncoordinated; the responsibility is divided between the central and the local executive bodies. As a result, coordination and methodological support of central and local executive bodies and local self-governments in implementing the national policy on combating social orphanage which entrusted to the Ministry of Social Policy of Ukraine. It founds that all important decisions concerning children are resolved at the level of Rayon Administration. The community of town village, remains away in solving these problems, it certainly does not concern the town of oblast significance, where the part of the executive committee is a service for children.

It also founds that the Law of Ukraine «On Local Self-Government» provided the community involvement to actively participate in addressing local community. However, the organization of such work locally undoubtedly requires resources.

It analyzes the approaches of resource classification, separated those which have (c) Л.П. Ящук, 2015
\end{abstract}


practical use and are used in the resource base making in the organization of combating against the social orphanage at the local self-government level.

It is proved that organization of combating social orphanage at the local self-government - is an activity using managerial methods and techniques that requires improvement conditions, forms and methods of providing social services to families who were in difficult life circumstances and resources - a set of opportunities for solving individual and social needs.

Key words: resources, the territorial community, organization of combating the social orphanage, a local self-government.

Постановка проблеми. Розвиток та вдосконалення системи сімейного влаштування дітей-сиріт та дітей, позбавлених батьківського піклування, є одним із пріоритетних напрямів соціальної політики України. Задля закріплення позитивних результатів та подальшого розвитку системи національного усиновлення та сімейного влаштування у 2012 р. були затверджені Національна стратегія профілактики соціального сирітства на період до 2020 р. та План за-

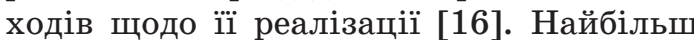
соціально вразливими є сім'ї з дітьми, які опинилися у складних життєвих обставинах, насамперед сім'ї, де батьки з певних причин (через тривалу хворобу, інвалідність, малозабезпеченість, безробіття тощо) не можуть забезпечити належного утримання та догляду за дитиною; сім'ї з дітьми, де члени сім'ї $\mathrm{\epsilon}$ особами з особливими потребами; сім'ї з дітьми, де батьки є трудовими мігрантами; сім'ї з дітьми, де батьки ухиляються від виконання батьківських обов'язків; сім'ї, в яких дитина або декілька дітей відібрані за рішенням суду від батьків без позбавлення їх батьківських прав. До групи ризику також можуть потрапити сім'ї опікунів чи піклувальників, прийомні сім' $і$, дитячі будинки сімейного типу, сім'ї, в які тимчасово влаштовані діти, які залишилися без піклування батьків або осіб, що їх замінюють. Відсутність належної превентивної соціальної роботи з такими сім'ями призводить до втрати виховного потенціалу сім'ї, позбавляє дитину можливості виховуватися в родині.

В Україні базовою при вирішенні соціальних проблем є інституційна модель, яка передбачає створення закладів і фінансування їх діяльності за рахунок державного бюджету. Як слушно зазначає Є.О. Парамонов, система державних органів та установ, які опікуються правами дитини в Україні, є нестабільною і перебуває у постійному русі. Вона змінюється, переформовується залежно від вимог часу та бачення означених питань керівництвом держави [15]. Адже створені заклади, як правило, організовують свою роботу згідно з розпорядженнями та інструкціями відповідних міністерств та відомств, що ускладнюе вирішення окремих соціальних проблем тих цільових груп, які безпосередньо проживають у конкретній територіальній громаді. Однак з прийняттям Закону України «Про місцеве самоврядування» запроваджена модель - соціальна робота в громаді, з використанням індивідуальних та групових методів роботи. Оскільки вищезазначеним Законом передбачено залучення громадськості до активної участі у вирішенні питань територіальної громади, пошук шляхів їх вирішення у співпраці з різними організаціями та структурами, які працюють на місцевому рівні та з метою організації результативної роботи з профілактики соціального сирітства, удосконалення системи соціальної роботи 3 сім'ями, що мають дітей і перебувають у складних життевих обставинах, то очевидно, що організація такої роботи на місцях безперечно потребує ресурсів. Ресурсне забезпечення діяльності місцевого самоврядування - сукупність предметів, об'єктів та засобів, за допомогою яких органи місцевого самоврядування реалізують свої повноваження, а також вирішують питання місцевого значення.

Аналіз досліджень і публікацій. Вивченням та аналізом ресурсів соціальної роботи присвячено ряд праць вітчизня- 
них та зарубіжних науковців. Безпалько O.В. - ресурсне забезпечення соціально-педагогічної роботи в територіальній громаді [3, с. 181], Варга С.I. [5]. Мирзеханова 3.Г. [13], [19], [20], [22] про необхідність концентрації первинної профілактики у місцевому самоврядуванні, 3 залученням ресурсів органів виконавчої влади та громадських, благодійних організацій зазначають - М. Бутко та Ю. Харченко [4]. Однак проблема ресурсного забезпечення в організації протидії соціальному сирітству на рівні місцевого самоврядування є малодослідженою.

Мета дослідження - виявити та класифікувати ресурсне забезпечення для організації протидії соціальному сирітству на рівні місцевого самоврядування на основі аналізу відповідних наукових підходів.

Виклад основного матеріалу. Координація та методологічне забезпечення діяльності центральних і місцевих органів виконавчої влади та місцевого самоврядування у сфері реалізації державної політики щодо протидії соціального сирітства покладена на Міністерство соціальної політики України. До структури Міністерства належать Департамент захисту прав дітей та усиновлення, Департамент сімейної, гендерної політики та протидії торгівлі людьми та Управління профілактики соціального сирітства, діяльність яких спрямована на забезпечення захисту прав, свобод та інтересів дітей. На обласному, міському та районному рівнях реалізацію державної політики у сфері захисту прав дітей, запобігання дитячій бездоглядності та безпритульності і координацію діяльності у сфері захисту прав дитини забезпечують служби у справах дітей [17]. На рівні територіальних громад соціальний захист та захист прав дітей забезпечують органи опіки та піклування, якими, відповідно до цивільного законодавства, є районні, районні в містах Києві та Севастополі державні адміністрації, виконавчі органи міських, районних у містах, сільських, селищних радах.

3 метою запобігання розриву сімейних зв'язків та попередження соціального сирітства зростає потреба в своєчасному виявленні сімей із дітьми у складних життєвих обставинах та наданні їм комплексних соціальних послуг за місцем проживання. Адже саме на рівні територіальної громади можна найбільш ефективно вирішувати проблеми формування сімейних цінностей та у разі потреби надання соціальної допомоги сім'ям, що опинилися в складних життєвих обставинах.

Формами надання послуг дітям, які опинились у складних життєвих обставинах, тимчасового перебування $€$ центри соціально-психологічної реабілітації дітей. Однак, незважаючи на свій потужний потенціал у наданні дітям індивідуальної психологічної та коригувальної допомоги, ці заклади $є$ малочисельними і також знаходяться на відстані від місця проживання дітей. Пройшовши курс реабілітації, дитина повертається до батьків, де залишаються ті ж проблеми, які були до поміщення дитини. Це з часом викликає необхідність повторного ізолювання дитини від сім'ї [14]. Як правило, діти які проживають у малозабезпечених сім'ях, ризикують потрапити до інтернатних закладів за заявою батьків у зв'язку з неспроможністю задовольнити потреби дітей через бідність чи безробіття. Перебування дітей у спеціалізованих закладах розглядається батьками як єдина можливість для їх дитини отримати належну медичну допомогу та освіту, що є великою помилкою, оскільки між батьками та дітьми руйнуються родинні зв'язки.

Соціальні послуги, що не передбачають стаціонарного перебування, надаються центрами соціальних служб для сім $\dddot{і}$, дітей та молоді [9]. Проте такі центри функціонують на рівні області, району та міста. Натомість заклади базової, первинної ланки - на рівні сільської та селищної громади - відсутні. Таким чином, сім`я, яка опинилась у складних життєвих обставинах, що проживає на території села або селища, може отримати соціальні послуги лише на рівні району, а не в конкретній громаді. Тож відсутність кваліфікованих послуг з підтримки батьківства за місцем проживання, бідність та безробіття призводять 
до того, що діти вилучаються із таких сімей або батьки самостійно влаштовують їх в інтернати. I це доводить Уповноваженим 3 прав дитини, станом на 01.01.2013 року в інтернатних закладах перебувало 117600 дітей (1,5 \% дитячого населення України), із них лише 13,5 тис. (11\%), тобто кожен десятий, має статус дитини-сироти або дитини, позбавленої батьківського піклування, решта - за заявами батьків [10, с. 3].

Практично всі об'єкти і явища, які оточують людей, являють собою ресурсний простір або ресурсну базу, тому головне - визначитися в питаннях необхідності та спрямованості їх використання. Ресурси - це будь-які джерела та передумови отримання необхідних людям матеріальних і духовних благ, які можна реалізувати при існуючих технологіях та соціально-економічних відносинах [2].

Слово «ресурс» походить від французького «ressourse» - допоміжні засоби, запаси, можливості, необхідні елементи людської діяльності [7].

Як зазначає С. Фолкман коли мова йде про допомогу конкретній людині доцільно брати до уваги ресурси особистості (здоров'я, витривалість, переконання, самоконтроль, психологічні характеристики тощо) та ресурси соціального середовища, представлені системою соціальної підтримки людини [11, c. 138].

А. Лауфер розглядає ресурси, що знаходяться в розпорядженні соціальних служб, людські, програмні та стратегічні. Ю. Фоа пропонує виділяти шість основних ресурсів у соціальній роботі: гроші, любов, інформацію, статус, послуги та товари $[8$, с. 26$]$.

До визначення видів ресурсів соціальної роботи, на думку Д. Томаса, варто підходити з позиції потреб громадян. 3 цієї точки зору доцільно поділяти ресурси на матеріальні послуги (виробництво, магазини, школи, сервісні заклади); засоби та форми організаційної й духовної підтримки (соціальні служби, громадські організації, церква); засоби міжособистісної підтримки та власна активність (самодопомога, взаємодопомо- га, підтримка членів родини, друзів та колег по роботі) [8, с. 27].

Досить оригінальною є класифікація ресурсів соціальної роботи К.С. Шендеровського. Він виокремлює велике коло ресурсів, зокрема:

$$
\text { - політичні (мета, завдання діяльнос- }
$$
ті);

- нормативно-правові;

- секторальні (державне - громадське - приватне);

- концептуальні (теорія);

- фінансові;

- адміністративно-управлінські;

- інституційні;

- етичні [25, с.53].

Але, розглядаючи ресурси соціальної роботи як об'єкт менеджменту соціальної роботи, зазначає, що це сукупність витрат політичних, матеріальних, технологічних, фінансових, інформаційних, кадрових, особистісних, які застосовуються для досягнення мети [24].

Класифікація ресурсів дає нам можливість виокремити ті, які мають практичне значення в процесі формування ресурсної бази в організації протидії соціальному сирітству на рівні місцевого самоврядування. До таких ресурсів належать: природні, фінансові, людські, інституційні, технологічні, інформаційні.

Відповідно до т. 142 Конституції України територіальна громада має свої ресурси «... рухоме і нерухоме майно, доходи місцевих бюджетів, інші кошти, землю, природні ресурси, що є у власності територіальних громад..., а також об'єкти їх спільної власності, що перебувають в управлінні районних та обласних рад» [12].

Природні ресурси можуть бути активно задіяні членами громади під час вирішення проблем дозвілля людей, ïx працевлаштування чи розвитку певних напрямів виробництва на території громади, а це - наявність лісопаркової зони, водойм, певних корисних копалин, особливостей географічного місця розташування, адже кожна громада розташована на певній території, яка має свої особливості.

Фінансові ресурси є необхідною 
умовою розвитку будь-якої територіальної громади. Організація і управління ними зорієнтоване, у першу чергу, на забезпечення стабільних i життево важливих фінансових потоків, пошук зовнішніх джерел фінансування. Фінансові ресурси територіальної громади поділяються на такі види: доходна частина місцевого бюджету; трансфери з Державного бюджету України; кошти загальнообов'язкового державного соціального страхування, які виплачуються жителям відповідної адміністративно-територіальної одиниці; кошти підприємств, установ і організацій, які спрямовуються на реалізацію соціальних програм; кошти благодійних і релігійних організацій, які спрямовуються на вирішення соціальних проблем у громаді; приватні кошти громадян [20, с. 164].

Для вирішення певних соціальних проблем у громаді залучаються зовнішні фінансові ресурси у формі грантів чи спонсорських надходжень від представників інших громад. Гранти можуть бути:

- цільові (спрямовані на сприяння будь-якій події чи заходу, наприклад реконструкції школи у сільській громаді);

- тематичні (призначені для підтримки ініціатив у будь-якій сфері соціально значимої діяльності, наприклад розвиток дитячої творчості чи працевлаштування людей 3 обмеженими функціональними можливостями);

- іменні (виділяються підприємцем чи певною компанією) [1, с.5].

Очевидним є той факт, що будь-яка діяльність не може здійснюватися без участі людей. Враховуючи, що саме на місцевому рівні безпосередньо реалізується переважна частина конституційних прав і свобод громадян та надаються основні послуги, гарантовані державою, постає питання щодо забезпечення органів місцевого самоврядування кваліфікованими та професійними посадовими особами, іншими словами - підготовленими кадрами. Тому людські ресурси відіграють провідну роль у соціальній роботі на рівні громади. Серед різновидів таких ресурсів можна визначати спеціалістів соціальної сфери (штатних соціальних працівників, соціальних педагогів, психологів, педагогів тощо), які виконують роль соціальних організаторів, членів ініціативних груп, залучених консультантів та волонтерів.

Розглядаючи ініціативну групу, наприклад, це не просто громадська комісія, а вона створена для розв'язання певної проблеми, що стосується всієї громади. Ініціативні групи складаються 3 членів громади та професіоналів, що їх підтримують та вони займаються проблемами, які стосуються всіх. Ключем до ефективного розвитку ініціативної групи є погляд на неї як на своєрідну «міні»-громаду. Створення ініціативної групи здійснюється за участю зацікавлених осіб. Кожна ініціативна група обирає для вирішення певні проблеми, аби стати ініціатором та учасником активних змін у громаді. У межах територіальної громади в залежності від їі чисельності може бути від однієї до кількох десятків ініціативних груп [6, с. 60].

Заслуговує на увагу думка російського дослідника I.Є. Кокарєва, який зазначає, що одним із важелів завдань кореневої, тобто ініціативної групи $є$ не тільки вирішення місцевих проблем, але й нарощення соціального капіталу, який визначається як потенціал взаємної довіри та взаємодопомоги, що формується в міжособистісному просторі [23, с. 115]. Соціальний капітал за своєю суттю охоплює різних представників громади як суб'єктів соціального життя, мережу їхніх взаємозв“язків, цінності та норми, яких вони дотримуються, а також різні види діяльності, здійснювані ними 3 власної ініціативи в рамках сформованої мережі зв'язків та з дотриманням усталеної системи цінностей і норм [21, с. 19].

Тому соціальний капітал можна теж вважати ресурсом, оскільки рівень його розвитку певним чином обумовлює ефективність роботи в організації протидії соціального сирітства на рівні місцевого самоврядування.

Не менш важливими у територіальній громаді є інституційні ресурси, діяльність яких координується на 
державному та місцевому рівнях. Найпоширеніші серед них: загальноосвітні заклади; позашкільні заклади; заклади системи охорони здоров'я, культури; різноманітні соціальні служби (соціальні служби для сім“ї, дітей та молоді, центри роботи з жінками, відділення соціальної допомоги, територіальні центри обслуговування пенсіонерів та одиноких непрацездатних громадян, центри соціально-трудової та професійної реабілітації інвалідів; реабілітаційні центри для дітей та молоді 3 функціональними обмеженнями; центри зайнятості, центри медико-соціальної реабілітації неповнолітніх; соціальні гуртожитки, клуби за місцем проживання тощо). Окрім перерахованих інституційних ресурсів, слід ще назвати такі види ресурсів, як церква та неурядові організації.

Організація протидії соціального сирітства в межах зазначених соціальних інституцій неможлива без використання різноманітних технологій. Технологічні ресурси - це сукупність форм, методів та прийомів, що застосовуються соціальними службами, закладами соціального обслуговування, громадськими організаціями, спеціалістами та волонтерами з метою задоволення потреб чи вирішення проблемних питань територіальної громади.

Звичайно, велике значення у протидії соціальному сирітству має інформаційний ресурс, який визначається як сукупність інформації на друкованих та аудіо-відеоматеріалах. Така інформація поділяється на зовнішню і внутрішню. Зовнішня сприяє підвищенню ефективності надання соціальних послуг користувачам. Внутрішня з усіх питань, що стосуються функціонування діяльності ресурсних центрів.

Для формування дієвих інформаційних ресурсів органів місцевого самоврядування необхідно дотримуватись наступних принципів: публічності ін- формації, якості надання населенню послуг, відкритості та прозорості у діяльності органів місцевого самоврядування, а також участі громадськості у питаннях місцевого значення. На нашу думку, одним із найважливіших інформаційних ресурсів, які використовуються у діяльності органу місцевого самоврядування, є офіційні інтернет-сайти.

Висновки. Таким чином, виявлено, що всі важливі рішення стосовно дітей вирішуються на рівні районної державної адміністрації. Громада міста села, селища залишається осторонь у вирішенні цих завдань, це звичайно не стосується міст обласного значення, де у складі виконкому є служба у справах дітей. Прикро констатувати, але у схваленій розпорядженням Кабінету Міністрів України від 1 квітня 2014 р. №333-р Концепції реформування місцевого самоврядування та територіальної організації влади в Україні [18] відсутні питання, які стосуються захисту прав дитини на місцевому рівні.

Зазначимо, що організація протидії соціального сирітства на рівні місцевого самоврядування - це діяльність 3 використанням управлінських методів та прийомів, що потребує вдосконалення умов, форм та методик надання соціальних послуг сім'ям, які опинилися у складних життєвих обставинах, а ресурси - це сукупність можливостей для розв“язання індивідуальних та соціальних потреб. Тож, розглянувши наукові підходи до ресурсного забезпечення та класифікувавши ресурси, переконані, що для організації протидії соціальному сирітству на рівні місцевого самоврядування необхідно залучити природні, фінансові, людські, інституційні, технологічні, інформаційні ресурси.

Перспективою подальших досліджень є профілактика соціального сирітства в умовах територіальної громади: зарубіжний досвід.

СПИСОК АIТРАТУРИ:

1. Автономов А. Хананашвілі, Н. Фонди як соціальна технологія міжсекторальної взаємодії // Добра воля. - 2004. - № 2-3. - С. 3-7.

2. Безпалько О. В. Соціальна робота в громаді : навч. посіб. [для студ. вищ. навч. закладів] / Безпалько О. В. - К. : ЦНЛ, 2005. - 176 с. 
3. Безпалько О. В. Теорія і практика соціально-педагогічної роботи з дітьми та учнівською молоддю в територіальній громаді [Текст] : дис. ... д-ра пед. наук : 13.00 .05 / Безпалько Ольга Володимирівна ; Ін-т пробл. виховання АПН України. - К., 2006. - 537 с.

4. Бутко М. П. Взаємодія органів державної влади та місцевого самоврядування у здійсненні соціального захисту дітей без батьківської опіки [Електронний ресурс] / М. П. Бутко, Ю. П. Харченко. - Режим доступу : http://vistnic.stu.cn.ua/index.pl?task=arcl\&j=9\&id=45. 5. Варга, С. І. Фінансові ресурси місцевого самоврядування: Дис. ... канд.. екон. наук: 08.04.01. - К., 2003. $-180 \mathrm{c.}$

6. Громада як осередок соціальної роботи з дітьми та сім“ями: Метод. матеріали для тренера / О.В. Безпалько та інші; Під заг. ред. І.Д.Звєрєвої . - К.: Наук. світ, 2004. - 69 с.

7. Інформаційні ресурси України: проблеми державного регулювання : монографія / за ред. О. В. Сосніна. - К. : НІСД, 2002. - 141 с.

8. Энциклопедия социальной работы. В 3 т. Т.3: Пер. с англ. - М. : Центр общечеловеческих ценностей, 1994. - $466 \mathrm{c}$.

9. Загальне положення про центри соціальних служб для сім’ї, дітей та молоді [Електронний ресурс] : Постанова Кабінету Міністрів України від 1 серпня 2013 р. № 573. - Режим доступу : http://zakon2.rada.gov.ua/laws/show/573-2013-п.

10. Звіт про здійснення Уповноваженим Президента України з прав дитини моніторингового дослідження стану функціонування закладів для дітей-сиріт та дітей, позбавлених батьківського піклування, дітей, які не мають необхідних умов для виховання та навчання в сім'ї, дітей з особливими потребами, ефективність використання такими закладами бюджетних коштів, спрямованих на забезпечення їх діяльності [Електронний ресурс]. - Режим доступу : http://www.president.gov.ua/docs/zvit2612.pdf

11. Клиники, дружественные к молодежи (пособие для организатора). - Новосибирск: Олден-полиграфия, 2002. - 264 с.

12. Конституція України [Електронний ресурс] : Верховна Рада України; Конституція, Закон від 28.06.1996 № 254к/96-ВР - Режим доступу : http://zakon2.rada.gov.ua/laws/ show $/ 254 \%$ D0 $\%$ BA $/ 96-\%$ D0 $\%$ B2\% D1\% 80

13. Мирзеханова З. Г. Ресурсоведение. - Владивосток, 2003. - 363 с.

14. Олифіренко Ю. І. Модернізаційні аспекти надання комплексної допомоги дітям, які опинились у складних життєвих обставинах / Ю. І. Олифіренко // Вісник Чернігівського державного технологічного університету. Серія «Економічні науки» : наук. зб. - 2013. - № 4 (70). - C. 496-501.

15. Парамонов Є. О. Актуальні питання захисту прав дитини в Україні [Електронний pecypc] / Є. О. Парамонов. - Режим доступу : http://lib.chdu.edu.ua/pdf/naukpraci/ govermgmt/2012/194-182- 7.pdf.

16. Про затвердження плану заходів з реалізації Національної стратегії профілактики соціального сирітства на період до 2020 року [Електронний ресурс] : Розпорядження Кабінету Міністрів України від 27.05. 2013 р.

№ 419. - Режим доступу : http://zakon2.rada.gov.ua/laws/show/419-2013-\% D1\% 80

17. Про органи і служби у справах дітей та спеціальні установи у справах дітей [Електронний ресурс] : Закон України від 24 січня 1995 року № 20/95-ВР. - Режим доступу : http:// zakon2.rada.gov.ua/laws/show/.

18. Про схвалення Концепції реформування місцевого самоврядування та територіальної організації влади в Україні [Електронний ресурс] : Розпорядження Кабінету Міністрів України від 1 квітня 2014 р. № 333-p. - Режим доступу : http://zakon4.rada.gov.ua/laws/ show /333-2014-p

19. Ресурсы инновации: организационный, финансовый, административный: Учеб. пособие для вузов / Под. ред. проф. И.П.Николаевой. - М.: ЮНИТИ-ДАНА, 2003. - 318 с.

20. Руденко В. Фінансово-матеріальні ресурси органів місцевого самоврядування як засоби реалізації соціальної спрямованості держави // Ресурси розвитку. Адміністративна реформа в Україні. / Упор. М.Пухтинський, Є.Рахімов. - К.: Логос, 2002. - С. 163-174.

21. Семигіна Т. Робота в громаді: практика й політика. - К.: Видавничий дім «КМ Академія», 2004. $-180 \mathrm{c}$.

22. Социальная работа / Под ред. В. И. Курбатова. - Ростов-на-Дону: «Феникс», 1999. $576 \mathrm{c}$.

23. Тренинги Народного Фонда. Расширенный каталог / Сост. Карасев Ф.Г., Карасева О.А. - М.: Прометей, 2011. - 128 с.

24. Шендеровський К. С. Вісімнадцять кроків до розуміння клієнта соціальної служби для дітей та молоді / Шендеровський К. С. - К. : КМЦССМ, 2002. - 76 с.

25. Шендеровський К. С. Взаємодія соціальних служб для молоді та громадських, 
благодійних організацій щодо задоволення потреб дітей, молоді, різних категорій сімей у м. Києві // Проблеми педагогічних технологій. Зб. наук. праць. Випуск 3-4. - Луцьк, 2004. - C. 63-72.

\section{REFERENCES:}

1. Avtonomov, A. Xananashvili, N. Fondy`yak social`na texnologiya mizh sektoral`noyi vzayemodiyi (Funds as social technology between sectoral interaction)// Dobra volya. - 2004. - № 2-3. - P. 3-7.

2. Bezpal`ko, O.V. Social’na robota v gromadi : navch. posib. [dlya stud. vy`shh. navch. zakladiv] (Social work in the community, teach. guidance). $-\mathrm{K} .: C z N L, 2005 .-176 \mathrm{p}$.

3. Bezpal`ko,O.V. Teoriya i prakty`ka social`no-pedagogichnoyi roboty`z dit’my` ta uchnivs`koyu moloddyu v tery torial'nij gromadi [Tekst] : dy`s. ... d-ra ped. nauk : 13.00.05 (Theory and practice of social and educational work with children and pupils in the local community [Text]: Dis. ... Dr. ped. Sciences: 13.00.05). In-t probl. vy xovannya APN Ukrayiny`. - K., 2006. - 537 p.

4. Butko, M. P. Vzayemodiya organiv derzhavnoyi vlady` ta miscevogo samovryaduvannya $u$ zdijsnenni social`nogo zaxy ‘stu ditej bez bat`kivs`koyi opiky` [Elektronny`j resurs] (Interaction of state and local governments in the implementation of social protection of children without parental care). - Access mode $:$ http://vistnic.stu.cn.ua/index.pl?task $=\operatorname{arcl} \& j=9 \& i d=45$.

5. Varga, S. I. Finansovi resursy` miscevogo samovryaduvannya: Dy`s. ... kand.. ekon. nauk: 08.04.01 (Financial resources of local government: Dis. Candidate ... .. economical. Sciences: 08.04.01). - K., 2003. - $180 \mathrm{p}$.

6. Gromada yak oseredok social`noyi roboty`z dit`my` ta sim‘yamy`: Metod. materialy` dlya trenera (The community as a center of social work with children and families: Method. materials coach) . - K.: Nauk. svit, 2004. -69 p.

7. Informacijni resursy` Ukrayiny`: problemy` derzhavnogo regulyuvannya : monografiya (Information Resources of Ukraine: problems of state regulation: monograph). - K. : NISD, 2002. $-141 \mathrm{p}$.

8. Entsiklopediya sotsialnoy rabotyi. V 3t. T.3: Per. s angl (Encyclopedia of Social Work. The 3T. V.3: Trans. from English). - M. : Tsentr obschechelovecheskih tsennostey, 1994. - $466 \mathrm{p}$.

9. Zagal`ne polozhennya pro centry`social`ny`x sluzhb dlya sim’yi, ditej ta molodi [Elektronny`j resurs] : Postanova Kabinetu Ministriv Ukrayiny vid 1 serpnya 2013 r. № 573 (General provisions on the centers of social services for families, children and youth [electronic resource]: Cabinet of Ministers of Ukraine dated August 1, 2013 p. № 573). - Access mode : http://zakon2. rada.gov.ua/laws/show/573-2013-p.

10. Zvit pro zdijsnennya Upovnovazheny`m Prezy`denta Ukrayiny` z prav dy`ty`ny` monitory`ngovogo doslidzhennya stanu funkcionuvannya zakladiv dlya ditej-sy`rit ta ditej, pozbavleny`x bat’kivs`kogo pikluvannya, ditej, yaki ne mayut neobxidny'x umov dlya vy xovannya ta navchannya v sim'yi, ditej z osobly'vy'my” potrebamy”, efekty 'vnist' vy`kory`stannya taky`my`zakladamy` byudzhetny`x koshtiv, spryamovany`x na zabezpechennya yix diyal nosti [Elektronny $\mathrm{j}$ resurs] (Report on the implementation of Commissioner President of Ukraine on children's rights monitoring study of the functioning of institutions for orphans and children deprived of parental care, children who do not have necessary conditions for education and training in the family, children with special needs, the effectiveness of such establishments budget to ensure their activities). - Access mode : http://www.president.gov. ua/docs/zvit2612.pdf

11. Kliniki, druzhestvennyie k molodezhi (posobie dlya organizatora) (Clinics, youth-friendly (for the benefit of the organizer). - Novosibirsk: Olden-poligrafiya, 2002. - $264 \mathrm{p}$.

12. Konsty`tuciya Ukrayiny` [Elektronny`j resurs] : Verxovna Rada Ukrayiny`; Konsty`tuciya, Zakon vid 28.06.1996 № 254k/96-VR (Konstitutsiya Ukraine [Electron resource]: the Verkhovna Rada of Ukraine; Konstitutsiya Act od 28.06.1996 № 254k / 96-BP). - Access mode : http:// zakon2.rada.gov.ua/laws/show $/ 254 \%$ D0\% BA/96- \% D0\% B2\% D1\% 80

13. Mirzehanova, Z. G. Resursovedenie (Resursovedenie). - Vladivostok, 2003. - 363 p.

14. Oly`firenko, Yu. I. Modernizacijni aspekty` nadannya kompleksnoyi dopomogy` dityam, yaki opy`ny`ly`s ' u skladny`x zhy`ttyevy`x obstavy`nax (Modernization aspects of providing comprehensive care to children in difficult circumstances) // Visny`k Chernigivs`kogo derzhavnogo texnologichnogo universy`tetu. Seriya «Ekonomichni nauky»»: nauk. $z b .-2013$. - № 4 (70). - P. 496-501.

15. Paramonov, Ye. O. Aktual`ni py`tannya zaxy`stu prav dy`ty`ny`v Ukrayini (Current issues of child protection in Ukraine). - Access mode : http://lib.chdu.edu.ua/pdf/naukpraci/govermgmt/2012/194-182- 7.pdf. 
16. Pro zatverdzhennya planu zaxodiv z realizaciyi Nacional`noyi strategiyi profilakty`ky` social`nogo sy`ritstva na period do 2020 roku [Elektronny`j resurs] : Rozporyadzhennya Kabinetu Ministriv Ukrayiny`vid 27.05. 2013 r. № 419 (On approval of the action plan to implement the National Strategy for the prevention of child abandonment in the period up to 2020 [electronic resource]: Cabinet of Ministers of Ukraine from 27.05. 2013 p. № 419). - Access mode : http://zakon2.rada.gov.ua/laws/show/419-2013-\% D1\% 80

17. Pro organy`i sluzhby`u spravax ditej ta special`ni ustanovy` u spravax ditej [Elektronny`j resurs] : Zakon Ukrayiny vid 24 sichnya 1995 roku № 20/95-VR (On the bodies and services for children and special institutions for children [electronic resource]: Law of Ukraine on January 24, 1995 № 20/95-VR). - Access mode : http://zakon2.rada.gov.ua/laws/show/.

18. Pro sxvalennya Koncepciyi reformuvannya miscevogo samovryaduvannya ta tery`torial`noyi organizaciyi vlady`v Ukrayini [Elektronny`j resurs] : Rozporyadzhennya Kabinetu Ministriv Ukrayiny vid 1 kvitnya 2014 r. № 333-r (On approval of the Concept of reforming the local selfgovernment and territorial organization of power in Ukraine [electronic resource]: Cabinet of Ministers of Ukraine on April 1, 2014 p. № 333-p). - Access mode : http://zakon4.rada.gov.ua/ laws/show/333-2014-r

19. Resursyi innovatsii: organizatsionnyiy, finansovyiy, administrativnyiy: Ucheb. Posobie dlya vuzov (Resources Innovation: organizational, financial, administrative: Proc. The manual for high schools). - M.: YuNITI-DANA, 2003. - $318 \mathrm{p}$.

20. Rudenko, $V$. Finansovo-material’ni resursy`organiv miscevogo samovryaduvannya yak zasoby`realizaciyi social`noyi spryamovanosti derzhavy` (Finansovo-materialni resources organiv mistsevogo samovryaduvannya yak zasobi realizatsiï sotsialnoï spryamovanosti powers)// Resursy' rozvy'tku. Administraty vna reforma v Ukrayini. - K.: Logos, 2002. - P. 163-174.

21. Semy gina, T. Robota v gromadi: prakty`ka j polity`ka (Robot in gromadi: Practice politika minutes). - K.: Vy`davny chy j dim «KM Akademiya», 2004. - 180 p.

22. Sotsialnaya rabota (Social work). - Rostov na Donu: «Feniks», 1999. - 576 p.

23. Treningi Narodnogo Fonda. Rasshirennyiy katalog (Trainings People's Fund. Enhanced Catalog). - M.: Prometey, 2011. -128 p.

24. Shenderovs`ky`j, K. S. Visimnadcyat` krokiv do rozuminnya kliyenta social`noyi sluzhby' dlya ditej ta molodi (Eighteen steps to understanding the client's Social Services for Children and Youth). - K. : KMCZSSM, 2002. - $76 \mathrm{p}$.

25. Shenderovs`ky j, K. S. Vzayemodiya social`ny`x sluzhb dlya molodi ta gromads`ky`x, blagodijny`x organizacij shhodo zadovolennya potreb ditej, molodi, rizny`x kategorij simej v $\mathrm{m}$. Ky yevi (The interaction of social services for youth and civic, charitable organizations to meet the needs of children, youth, families in different categories meters. Kiev)// Problemy pedagogichny`x texnologij. Zb. nauk. pracz`. Vy`pusk 3-4. - Lucz`k, 2004. - P. 63-72.

Ящук Лариса Петрівна - аспірант

Національна академія державного управління при Президентові України

Адреса: 03057, м. Київ, вул. Ежена Потьє, 20

E-mail: Laurum@ukr.net

Yashchuk Larisa Petrivna - postgraduate

National academy for public administration under the President of Ukraine

Address: 20, Ezhena Pottier Str., Kyiv, 03057, Ukraine

E-mail: Laurum@ukr.net 